\title{
Professional knowledge in primary health care of the person/family in mental distress: Le Boterf perspective
}

\author{
SABERES PROFISSIONAIS NA ATENÇÃO PRIMÁRIA À SAÚDE DA PESSOA/FAMÍLIA EM \\ SOFRIMENTO MENTAL: PERSPECTIVA LE BOTERF
}

\author{
LOS CONOCIMIENTOS PROFESIONALES EN LAATENCIÓN PRIMARIA DE LA SALUD \\ DE LA PERSONA/FAMILIA EN LA ANGUSTIA MENTAL: PERSPECTIVA LE BOTERF
}

\section{Roselma Lucchese ${ }^{1}$, Paulo Castro ${ }^{2}$, Serigne $\mathrm{Ba}^{3}$, Vagner Rosalem ${ }^{4}$, André Silva ${ }^{5}$, Márcio Andrade ${ }^{6}$, Denize Munari ${ }^{7}$, Inaina Fernandes ${ }^{8}$, Hilton Neves $^{9}$}

\begin{abstract}
Aim of this study was to identify knowing-doing actions constituted the practice of Family Health (FH), in view of nurses in relation to the person and family care in mental distress in terms of professional knowledge of Le Boterf. Method: Descriptive exploratory qualitative study, to deepen contruction of nurse in FH. The survey was conducted in 3 Units FH. Result: Doing a thematic analysis, came to the following categories: "Knowing how to act and react with relevance"; "Knowing how to combine resources and mobilize them in a professional context"; "Knowing how to interact with multiple knowledges"; "Knowing how to transpose"; "Knowing how to learn and knowing how to learn to learn"; "Knowing how to engage". Final considerations: the greatest difficulty was "be able to transpose," and that the daily demand of the $\mathrm{FH}$ teams requires a lot of this knowledge. Little transposition of knowing-doing in real situations has been verified.
\end{abstract}

\section{DESCRIPTORS}

Nursing

Family health

Mental health

Clinical competence

\section{RESUMO}

O objetivo deste trabalho foi identificar os saberes e fazeres constituídos na prática da Saúde da Família (SF), na visão dos enfermeiros, no que se refere ao atendimento à pessoa e família em sofrimento mental na perspectiva dos saberes profissionais de Le Boterf. Método: Foi feito uma pesquisa descritiva exploratória de abordagem qualitativa, delineada para apresentar e aprofundar a construção de competências dos profissionais enfermeiros, foi aplicada em 3 Unidades da SF. Resultados: fazendo uma análise temática, chegou-se às seguintes categorias: "Saber agir com pertinência"; "Saber mobilizar saberes e conhecimentos em um contexto profissional"; "Saber interagir saberes múltiplos"; "Saber transpor"; "Saber aprender e saber aprender a aprender"; "Saber envolver-se". Considerações finais: verificou-se que entre os saberes a maior dificuldade é a de "saber transpor", e que o cotidiano das equipes de SF exige muito desse saber. Foi verificado pouca transposição de saberes/fazeres em situações reais.

\section{DESCRITORES \\ Enfermagem \\ Programa saúde da família \\ Saúde mental \\ Competência profissional}

\section{RESUMEN}

El objetivo del estudio fue identificar los conocimientos y acciones en la práctica de la Salud de la Familia (SF), a la vista de las enfermeras en relación con la persona y la familia en el cuidado angustia mental en términos de conocimientos profesionales de Le Boterf. Método: Un estudio cualitativo exploratorio descriptivo, se indica para introducir y profundizar en el desarrollo de habilidades de las enfermeras, aplicado a 3 unidades SF. Resultados: hacer un análisis temático, llegó a las siguientes categorías: "Saber actuar correctamente"; "Conociendo a movilizar conocimientos y experiencia en el ámbito profesional"; "Sabiendo que interactúan múltiples saberes"; "Sabiendo transponer"; "El saber aprender y saber cómo aprender a aprender"; "Sabiendo participar". Consideraciones finales: se encontró el conocimiento de la mayor dificultad es la de "ser capaz de incorporar", y que los equipos diarias SF requiere mucho este conocimiento. Poco transposición del saber/hacer en situaciones reales ha sido verificada.

\section{DESCRIPTORES \\ Enfermaria \\ Salud de la familia \\ Salud mental \\ Competencia clínica}

${ }^{1} \mathrm{PhD}$ in Nursing, Federal University of Goias, Catalao Region. Catalao, Brazil. ${ }^{2} \mathrm{PhD}$ in Science, Federal University of Goias, Catalao Region.Catalao, Brazil. ${ }^{3} \mathrm{PhD}$ in Education, Federal University of Goias, Catalao Region. Catalao, Brazil. ${ }^{4} \mathrm{PhD}$ in Business Administration, Federal University of Goias, Catalao Region. Catalao, Brazil. ${ }^{5} \mathrm{PhD}$ in Psichology, Federal University of Goias, Catalao Region. Catalao, Brazil. ${ }^{6} \mathrm{MBA}$ in Interpreteur Managment, Federal University of Triangulo Mineiro, Campus Paracatu. Paracatu, Brazil. ${ }^{7} \mathrm{PhD}$ in Nursing, Federal University of Goias, Catalao School of Nursing, Catalao, Brazil. ${ }^{8}$ Specialist in Biological Science, Federal University of Goias, Catalao Region. Catalao, Brazil. ${ }^{9}$ Master of Nursing, University of Cuiaba, Departament of Nursing, Cuiaba, Brazil. 


\section{INTRODUCTION}

The construction of the integrality of health care daily challenges the disruption of hegemonic paradigms, especially when it comes to primary health care (PHC). In this context, a challenge is the mental health care in Family Health $(\mathrm{FH})$, when we consider the principles of the Health Reform and the Psychiatric Reform ${ }^{(1)}$, in other words, it would seek to provide integrality of health care through the psychosocial aspects of care.

These reform processes are linked in many senses, as they presupposes the concept of health from the needs of the individual and family, the logic of territoriality, personal autonomy and popular participation ${ }^{(1,2)}$. We understand that the psychosocial care may guide the practice of PHC, since they converge and potentialize it.

In order to make mental health care to be based on these assumptions, changes are fundamental and desirable in the field of policies, management, practices of health, society and the training of health professionals in universities and in the service. The latter requires the creation of new knowing-doings of health care, combined to these assumptions, so PHC and psychosocial care, since they refer to practices in reintegration and retention of the subject in mental distress of his/her social life.

It is noteworthy that the relationship between the front door of the $\mathrm{PHC} / \mathrm{FH}$ and community is also the foundation of the proposed replacements to the psychiatric hospitalization services ${ }^{(3)}$. However, what most undermines the effectiveness of $\mathrm{FH}$ as a reorientation strategy of care model in quality of care producer is the persistent influence of the traditional biomedical model of health practices performed in this space. This process minimizes the work of $\mathrm{FH}$ program and weakens the process of formation of new health practices, lasting the concept of health as the absence of disease, pain and death ${ }^{(4)}$.

Moreover, this reality also reappears when we seek to understand the limits and possibilities of psychosocial care. The psychiatric paradigm historically led the mental health practices by the nexus of social exclusion and medicalization practiced in psychiatric hospitals. Being common to find health professionals in PHC, who are touched by the person suffering mentally, but are not prepared to handle this situation ${ }^{(5,6)}$, which is complex because it requires mobilization of competences and knowledge beyond the logic centered on disease.

Acting in a complex situation requires professional competence, in other words the ability to articulate resources such as knowledge, skills, values and norms of the real situation, when it is done "what should be done". In these features, we find the savoir-faire (knowing-doing) and perception, thinking, judgment and assessments schemes $^{(7)}$. The theoretical framework is from Le Boterf, in order to be competent it is necessary to perform what is prescribed and go beyond, acting on the unpredictable situations and contingencies. The competent professional makes decisions, initiative, negotiates, chooses, provides resources, take risks and predict incidents ${ }^{(8)}$.

For mobilizing and combining resources in managing a complex situation, instrumentation of professional knowing/doing is necessary, such as knowing how to act and react pertinently, how to combine resources and mobilize them in context, knowing how to transfer, namely knowing how to learn to learn and knowing how to engage ${ }^{(8)}$.

The service for a person who is suffering mental distress and his/her family in $\mathrm{PHC}$ is a complex situation, it requires team decision making, requiring knowledge and competences in the context of psychosocial care, such as care for the family. Therefore, the object of this study was knowingdoing for mental health care in $\mathrm{PHC}$, considering the nurse as an articulator of this knowledge, by her/his strategic position as team manager of PHC. From these considerations, we were interested in the repertoire of resources for nurses in $\mathrm{PHC}$, in order to care for the person in mental suffering, which knowing-doing actions are constructed by nurses in their training and/or professional life.

Thus, the present study aimed to identify knowing-doing constituted in the PHC practice, in the view of nurses to meet the person and family in mental suffering in terms of professional knowledge of Le Boterf. As mental suffering, this study considered people with mental disorders and their various levels (serious/persistent/moderate/ mild), diagnosed or self-referred, who live within the PHC territory.

\section{METHODS}

Exploratory descriptive study with qualitative approach, which presents and deepens the construction of competences of nurses in mental health in the FH program. It was conducted in a city in the State of Mato Grosso (MT) with approximately 85,857 inhabitants, which meets semi-complete system of health care, represented in PHC for nine Family Health Units (FHU) (seven local and two rural), six rural Basic Health Units of Health and one emergency service 24 hours, one Psychosocial Care Center I (PCC).

The research was conducted in three FHU, between March and April 2008, being the subjects involved three nurses and other members of the health team, totaling 33 participants in the study, since the reality of care was observed by the researcher, the entire team was oriented about the study and consented to observation. For setting and subject selection, inclusion criteria were FHU used as practice field for undergraduate
Professional knowledge in primary health care of the person/ family in mental distress: Le Boterf perspective

Lucchese $R$, Castro $P$, Ba S, Rosalem V, Silva A,

Andrade $M$, Munari $D$, Fernandes I, Neves $H$ 
Nursing course with an active on-site nurse for more than two years.

The choice for the FHU as our field for the research was done due to the fact that classes and internship of undergraduate Nursing were conducted there, showing the importance of these spaces in the training of new professionals. As it is expected that there is a sensitivity to mental health care in the PHC learning context.

For data collection, the researchers remained a week in each FHS using script (field diary) observation of routine service and semi-structured interviews with nurses. The questions stimulated a dialogue about practice in relation to mental health in the daily service. Before the beginning of data collection, nurses and other team members signed the consent form.

The interviews were recorded and transcribed in full, together with the contents of a field diary underwent a method of content analysis, thematic type ${ }^{(9)}$. The registration units were coded in $\mathrm{N}(1), \mathrm{N}(2)$ and $\mathrm{N}(3)$ for nurses, and $\mathrm{O}(1), \mathrm{O}(2)$ and $\mathrm{O}(3)$ for observational quotes.

The analysis process was related to constituted knowledge and that the situation did constitute complex situation of mental health care in the FH unit, which eventually comprised pre-defined categories, according to the theory of Le Boterf. This theory is based on the teaching of competences, comprising competence as the ability to evoke knowing in action to manage a complex situation ${ }^{(8,10)}$.

The predefined categories were "Knowing how to act and react with relevance"; "Knowing how to combine resources and mobilize them in a professional context"; "Knowing how to interact with multiple knowledge"; "Knowing how to transfer"; "Knowing learning and knowing how to learn to learn"; "Knowing how to engage". Guided by the Resolution 196/96, (current at the time) the project was approved by the Ethics Committee in Research of the Julio Muller Teaching Hospital - protocol 451/CEPHUJM/07.

\section{RESULTS AND DISCUSSION}

Three nurses participants of the research completed the undergraduate nursing course between the years 2004-2005 and were specialist in Public Health. All of them studied in the same state of the research.

Data were synthesized in a Box, which illustrates the pre-defined categories and indicate constituent knowledge from studied competences. For knowledge, which have not been incorporated into the action of the professional studies, there are examples extracted from their statements or observations, followed by indicators that they are relevant to each specific knowledge.

Box 1 - Categories and their dimensions accompanied by fragments of statements (registry units) approaching or not approximations of the constitution of knowledge and practice in FH mental health. MT, 2009.

Knowing how to act and react with relevance

Knowing what to do; Knowing how to go beyond prescription; Knowing how to choose the urgency; Knowing how to arbitrate, negotiate, decide; Knowing how to proceed depending on the outcome.

\begin{tabular}{|c|c|}
\hline Approach & No approaching \\
\hline $\begin{array}{l}{[. . .] \text { once, I went to the home of a user who knew I treated that }} \\
{[\ldots] \text { was hospitalized [...] I went there with the police, we sedated }} \\
\text { him and sent him for the emergency of a psychiatric hospital. } \\
N(1) \\
{[\ldots] \text { We don't have places to where we can bring these people }} \\
\text { even in our private life, we do not have places where we can take } \\
\text { them for treatments, PCC in here does not attend acute crisis. } \\
\text { N(2) } \\
{[\ldots] \text { The physician and I have already found vacancies for two }} \\
\text { hospitalization [...] those treated in PCC I know very little. } N(3) \\
\text { We have programs for pregnant women, prenatal care, } \\
\text { hypertensive people, people with diabetic, tuberculosis program, } \\
\text { in these cases we are experts! Why? }\end{array}$ & $\begin{array}{l}\text { [...] People want the consultation and the medicine, [...], if I don't } \\
\text { have it in my unit, it isn't worth [...] the physician arrives, attend } \\
\text { a lot of people fast, brings a lot free sample of medicine, and it } \\
\text { is okay, he is a great FHS physician [...] and I'm here with this } \\
\text { bunch of reports to finish. N(3) } \\
\text { Assessment protocols, a patient arrived and presents such } \\
\text { symptoms [...] if had a protocol, and experience from the contact } \\
\text { with the patient [...] the FHS nurse would be able to do better } \\
\text { prevention, so we have to standardize this care. N(1) } \\
\text { [...] We have no records of notification or a way to work with this } \\
\text { type of patient on violence, aggression, sexual abuse, drugs; we } \\
\text { have no means to work. } N(2)\end{array}$ \\
\hline
\end{tabular}

Knowing how to combine resources and mobilize them in a professional context

Knowing how to combine competencies from resources; Knowing how to take advantage not only of incorporated resources (knowledge, knowhow, qualities), but also the resources of their environment. 


\begin{tabular}{|c|c|}
\hline Approach & No approaching \\
\hline $\begin{array}{l}{[\ldots] \text { Then the school chooses the theme that is needed there [...] I leave }} \\
\text { this autonomy so that people may choose a theme they really need, and } \\
\text { then we organize activities. N(1) } \\
\text { [...] That woman who comes here every two weeks with that tightness in the } \\
\text { arm, who is always rude to treat people that is a key point for us to look } \\
\text { for something else. N(2) } \\
\text { This is how I follow this type of patient, if he/she does not progress there } \\
\text { again [...] we refer them to appropriate institutions to deal with these } \\
\text { types of problems. N(1) } \\
\text { [...] Then I went to her home [...] she was with a lady who took care of her, } \\
\text { she was singing and screaming [...] I brought her to the unit and referred } \\
\text { her to PCC. N(2) } \\
\text { For example, when the patient arrives at the health unit here, we have an } \\
\text { ally that is the CHA, because he lives in the community, then it becomes } \\
\text { easier for us to identify those patients who have some kind of suffering [...] } \\
\text { it is good when you are always in the same place, you know all its micro } \\
\text { area, I know everyone who comes here. N(2) }\end{array}$ & $\begin{array}{l}\text { We referred him to a professional, as we are lay in Mental Health we } \\
\text { referred [...] he was diagnosed with schizophrenia [...] look, it was } \\
\text { through the General Hospital we managed to mobilize the psychiatrist, } \\
\text { because here we do not have PCC, so he went to the Psychiatric Hospital. } \\
\text { N(2) } \\
\text { [...] I was afraid of her getting hurt, because you know, we should expect } \\
\text { any kind of attitude, you know why I referred immediately to PCC. N(3) } \\
\text { [...] Working with the suffering of people is very difficult, it is something } \\
\text { that involves other sectors, only the family health team is not enough [...] } \\
\text { and I say this to the management, and other services that make up the } \\
\text { network. N (3) } \\
{[\ldots] \text { I do not know how many users of Mental Health has in its area. O (1) }} \\
{[\ldots] \text { He was hospitalized [...] I went there with the police, sedated and sent }} \\
\text { him for the emergency of a psychiatric hospital. N(1) }\end{array}$ \\
\hline
\end{tabular}

\section{Knowing how to transpose. Knowing how to interact with multiple knowledge}

Knowing how to memorize multiple situations and standard solutions; Knowing how to distance themselves, work on a "two-way road"; Knowing how to mobilize their metaknowledge to make it standard; Knowing how to determine and interpret indicators of context; Knowing how to create the conditions for transferability with the aid of transferable schemes.

\begin{tabular}{|c|c|}
\hline Approach & No approaching \\
\hline $\begin{array}{l}\text { [...] If we think health as not merely the absence of disease, looking at } \\
\text { people's suffering enables us to understand mental health [...] N(3) } \\
\text { [...] Experience is what is lived, practiced, to see if it is what happens [...] } \\
\text { N(1) } \\
\text { [...] This contact with the community is important, it would not be a } \\
\text { contact only in literature, in a book [...] each time is a different thing, } \\
\text { sometimes the individual does not even need a medication, just a } \\
\text { conversation, a dialogue, guidance, information, then this part here we } \\
\text { exercise this working tool that is communication [...] N(1) } \\
\text { [...] In FHS, which you are responsible for, you have decision, you have } \\
\text { the actions [...] you experience problems inside the home of patients. N(2) } \\
\text { [...] Complaints that bring people here are the same [...] but interventions } \\
\text { that I do are not equal, each person has a different story that they tell us } \\
\text { [...]N(3) } \\
\text { [...] Thus there is also suffering [...] in most homes here, we do not have } \\
\text { enough to eat! They have no sanitation, no proper hygiene, there are no } \\
\text { jobs for everyone [...] in schools through lectures, we guide on hygiene, } \\
\text { but there are children who go to school in the morning and does not } \\
\text { shower. And the first food he/she has is in school. This suffering is a broad } \\
\text { thing [...] so to speak only with education, with community involvement. } \\
\text { N (1) }\end{array}$ & $\begin{array}{l}\text { [...] I have talked about it in the secretary office, but not even the } \\
\text { responsible for the health of the family gave me attention [...] I was in } \\
\text { the social action, talked seriously with the social workers, now let's see } \\
\text { [...] Because this money help support the family, then we have to think of } \\
\text { something else you know. N(3) } \\
\text { [...] You develop all the skills and competencies to manage the } \\
\text { administrative and assistants parts, you can do this here in a family health } \\
\text { program [...] N(1) } \\
\text { Nurse and nursing technician are screening for medical consultations, } \\
\text { technician, in turn, verify the vital signs and the nurse records in the } \\
\text { chart and asks the reason for medical consultation, but does not find any } \\
\text { correlation between subjective data with physical complaints and data } \\
\text { collected by the nursing technician. O(3) } \\
\text { A user came to the unit, reporting that a week before she had felt at her } \\
\text { home and severed hurt her left leg (deep cut with bad aspect), and she } \\
\text { was at home washing the cut with herbs. The nursing technician held the } \\
\text { bandage without comment (would the patient be using any medication, } \\
\text { vaccines, fever, palpable inguinal node) and did not ask her to return for } \\
\text { other dressings or other assessments. O(3) }\end{array}$ \\
\hline
\end{tabular}

Knowing to learn and knowing how to learn to learn

Knowing how to draw the lessons of experience; knowing how to transform their actions into experience; Knowing to describe how to learn; Knowing how to act

\begin{tabular}{|c|c|}
\hline Approach & No approaching \\
\hline $\begin{array}{l}\text { [...] She was about 29-30 years old when she had her first pregnancy and } \\
\text { she had postpartum depression [...] she was treated with a psychologist, } \\
\text { that we had at the time in the health department and in the regional } \\
\text { hospital [...] she adhered to drug treatment, everything right [...] Then } \\
\text { she got pregnant again [...] we began to encourage her to seek readings, } \\
\text { to improve her relationship with her spouse, with family members [...] } \\
\text { she had many arguing problems with her husband, it was hard to find } \\
\text { a job [...] we tried to find a job for the spouse [...] then the husband } \\
\text { started working, it was less a problem for her to get out of this depression } \\
\text { [...] she became more communicative, a reasonably person without any } \\
\text { psychological problem. } N(2)\end{array}$ & $\begin{array}{l}\text { [...] we didn't have an anatomy lab in our college [...] We didn't have } \\
\text { internship and there were no professors or had no training field [...] So } \\
\text { today if someone arrives and asks me if I was trained in mental health } \\
\text { [...] Because I did not have it in my under graduation. N(1) } \\
\text { [...] We have to fill } 19 \text { reports every month, and we only have } 22 \text { useful } \\
\text { days [...] how can we do prevention, groups, visits [...] N(2) } \\
\text { [...] The nurse stayed little on the unit today, it was day of closing and } \\
\text { delivery of reports and nurses must take it to the health department } \\
\text { (Friday, day of the team). O(3) } \\
\text { While the nurse and the nursing technician performed screening in } \\
\text { children (vital signs and anthropometric data) these were weighted with } \\
\text { clothes, not recorded in the vaccination card, just in the chart, did not } \\
\text { relate the weight, immunization, with the social context of children. O(1) }\end{array}$ \\
\hline
\end{tabular}

Continued...

$\begin{aligned} \text { Rev Esc Enferm USP } & \text { Professional knowledge in primary health care of the person/ } \\ 2014 ; 48(E s p 2): 123-131 & \text { family in mental distress: Le Boterf perspective } \\ \text { www.ee.usp.br/reeusp/ } & \text { Lucchese } R \text {, Castro } P, B a S, \text { Rosalem } V \text {, Silva A, } \\ \text { Andrade } M \text {, Munari } D, \text { Fernandes I, Neves } H & \end{aligned}$




\begin{tabular}{l|l}
\hline \multicolumn{1}{|c|}{ Approach } & \multicolumn{1}{c}{ No approaching } \\
\hline [...]Will we get the medicine? Suffering is something we see in our routine! & [...] if we do not find a solution for this, her treatment will complicate, it is \\
Who is a FHS nurse has to know how to deal with suffering [...] suffering & not in the books, because in that house, things work around that mother. \\
is double! Because I have to talk to the individual and the family, as & $N(3)$ \\
though he could have a consultation, he will need the drug [...] there is & [...] The own service demand (at secondary and tertiary level) there \\
also suffering from anxiety from the team [...] when a CHA goes home, the & ends up engulfing you, and not here, you see here we talk [...] you have \\
first thing they ask is if there is medicine in the unit, if they are doing tests? & a commitment to the population with the individual [...] you will be a \\
So, nowadays anyone who comes to the unit, is already suffering from & $\begin{array}{l}\text { better professional, will have the commitment, responsibility towards the } \\
\text { patient. N(1) }\end{array}$ \\
\hline psychological distress. N(1)
\end{tabular}

Among the knowledge constructed and the knowledge to be constructed regarding the psychosocial model, there is an interplay between what is proposed and what is done. Because we are approaching the $\mathrm{FH}$ program, which have innovative health purposes as capable of breaking the mediocre model of service care, by structuring the territory/domicile of the people, evoking a view that enables professionals to take care of totality, integrality of these subjects ${ }^{(11)}$. Since this characteristic of visiting homes of people a road of opposite directions, which can either promote the autonomy of users of the Unified Health System (SUS) or reaffirm/strengthen health practices centered on medications/pathology $y^{(6,12)}$.

In this contradictory space, we seek the constitution of knowledge. The first category "Knowing how to act and react with relevance", operates beyond what is there, not only execute the prescribed, but also overcome $i^{\left({ }^{(8)}\right.}$. Regarding the concept "Knowing what to do" is constituted in relations in which the interviewees are placed responsible for the people who watched and heard the suffering in its multiple dimensions and contexts; acted targeted to their real needs, certainly valued interpersonal relations and progressed in integrality of care. Thus, clarifying the space of interpersonal relations as a possible knowingdoing beyond prescription.

This relational field is placed at the service of therapeutic goals, justifying the participation of matrix support (MS) of mental health professionals, which should here be represented/performed by $\mathrm{PCC}^{(12)}$.

However, concerning the other concepts from this category, tools that could support a network of psychosocial care emerged, given the vagueness of mental health programs in PHC, especially in the MS team. Looking back, it is PCC's responsibility to organize the care network in mental health and MS, with inclusion in the Primary Care Information System. The MS is a strategy of interaction between the teams in a given territory, with planning and implementation of joint actions in the care of mental health issues ${ }^{(13)}$.

The desirable within the psychosocial paradigm, is that the actions of mental health teams are facing the suffering of the subject and their social body ${ }^{(14)}$, and we understand that this space is only possible in the context of performance of $\mathrm{FH}$ program.

An experience of joint work between FH and PCC indicated significant gains, initiated by the implementation of work in Inter-teams, which both serve as assistance to users of the service as a professional qualification. This work was perceived from the reframing of conceptions about the person suffering mentally, to expand the capacity of mental health intervention, with better management of groups, consistent consumption of drugs, reduction in referrals to specialist services ${ }^{(15)}$.

In this research, we observed a deficient reality of MS and may be one of the factors facilitating health actions guided by the physician-psychiatric model, as in cases of urgency, the mental patient is assisted with the aid of the police and sent to the hospice. Contrary movements to the relevant act of psychosocial care. This is not an isolated incident, since the difficulty of mental health from the $\mathrm{FH}$ was already proven by research conducted at the national level ${ }^{(11)}$.

Thus, fighting for the construction of relevant psychosocial care and the establishment of a knowledge network is to optimize and guide integrality of care to health in $\mathrm{FH}$. Thus, in FH territory achieved goes far beyond the geographical field, enabling professionals to deal with human suffering, in which subjects experience the relationship subject/family with the $\mathrm{FH}$ team ${ }^{(12)}$.

The possibility of this different knowing-doing is also developed through the care tool, which reveals evidence for self-care, responsibility in the therapeutic process, in the motivation of multidisciplinary teamwork, in addition to qualifying practices of attention to the health needs of citizens ${ }^{(16)}$, noting that the knowledge in the cited dimensions is in line with the area of mental health and addresses the understanding of the person, adding to the integrality of health care. So, counting on mental health in the actions in $\mathrm{FH}$ gives opportunity to consolidate a work focused on integrality of individuals/family ${ }^{(17,12)}$.

We also observed the facility of $\mathrm{FH}$ teams to act in oriented preformatted programs by the Brazilain Minis- 
try of Health (BMH), subsidizing health actions. It seems that while this organization promotes actions in the bureaucratic sense to serve, it limits the creativity and innovate in overcoming health practices, especially in mental health issues, which is excluded in these programs.

This is the prescriptive knowledge that reference to professional occupation, as safety rules, respect for professional and instrumental requirements. Relevant to a bureaucratic competence in establishing and socializing with functions, routines, standards of services, the model inherited characteristic of Taylorism and Fordism, in which the subject is an operator with limited ability and know how to perform the required operations ${ }^{(8)}$.

In this research, the prescriptive emerged as a "cooking recipe", a protocol to be followed, not feasible to interpersonal aspects.

The prescriptive knowledge is reinforced when working in $\mathrm{FH}$ oriented programs, ie, professionals respond to procedures established by management, such as vaccination coverage, surveillance and control of chronic and infectious diseases, prenatal, hiperdia, among others. These health care services are measured in the form of reports, their care is guided by handbooks.

In this direction, a study that analyzed the national literature regarding mental health care in primary care, found contradictions in the practice of integrality of care for people in mental suffering and family with restricted actions to drug treatment, remission of symptoms and disarticulation with family member ${ }^{(11)}$.

This provision of actions reinforces the bureaucratic and biomedical knowledge in health care, preventing the democratization of the values assigned to multidisciplinary knowledge, in the transdisciplinary version in the construction of integrality of care. The prescriptive character became clear in all three $\mathrm{FH}$ teams investigated, with impregnation of practices instituted in health, as if the actions were plastered by system management. The preformatting actions is so present in everyday of $\mathrm{FH}$ units, that a verbalized solution was just to create "protocol" for integrality of health care.

The records in a field diary corroborated by unveiling the conduct of the quoted view, an organization focused on serving the health service centered on biological factors. The attention to people who sought FH was timely and fragmented, addressing solicitations that are directed to the surface without large investigations or deepening.

We understand these situations as complex as they involve a (de)value of the subjectivity of the subject, in a context that would estimate this dimension of care, such as the inter-relationship and role of actors. Thus, the professional must manage a situation in a different context, ie, knowing how to act is knowing how to interpret ${ }^{(8)}$.
Regarding the second category "Knowing to combine resources and mobilize them in a professional context" revealed by knowledge mobilized in real situations ${ }^{(8)}$ within the $\mathrm{FH}$ program. Also, we demonstrate competencies, since they are manifested by determined actions, mobilize, integrate and use knowledge and skills in action. Such knowledge can be distinguished in declarative (laws, facts), procedural (methodological) and conditional, which determine the legitimacy on what were applied the procedural $^{(7)}$. However, they aggregate corporate resources (knowledge/competencies) and aimed (machines, database, documents) and transposes these into action.

Thus, a competent nurse, would be one that mobilizes knowledge/competencies and other resources acquired, and applies them using other components that the environment provides. In this research, the relationship between the nurse and the subject/family in $\mathrm{FH}$ enabled/enables this "mobilizing resources" beyond the prescriptive knowing-doing. Listening to the community and giving them space to expose their needs was a way for the construction of autonomy, co-responsibility, as well as looking at the subject and paying attention to the differences, prejudice and revealing real needs (family/community). Position understood as learning to build features associated with the resources of their environment.

In the $\mathrm{FH}$ program, professionals see people on the network where they organize their lives, therefore, they should no longer be numbers and answers to questionnaires of instituted programs ${ }^{(12)}$. However, this strategy requires a lot of work, since it challenges the co-participation of health services and communities in building effective and practical in resolving attention and bond, welcoming and humanized/humanistic care ${ }^{(4)}$.

Another resource of the work environment of $\mathrm{FH}$ mobilized and considered essential in the construction of the attention to the person in mental distress, the inclusion of Community Health Agents ( $\mathrm{CHA}$ ) in the logic of territoriality. Certainly, in this relation there are mutual benefits for both, as territoriality discussed by several studies ${ }^{(6,11,15)}$, it substantiates the existence and practice of $\mathrm{CHA}$ in $\mathrm{FH}$. $\mathrm{CHA}$ are inserted in the community where they operate, moving between them and the health service, as a mediator and facilitator of work activity in primary care ${ }^{(18)}$.

Perhaps, this is one factor that increases the capacity of the $\mathrm{FH}$ worker to overcome medicalized practice in caring for people in mental suffering, approaching the singular look at the health-disease process, the availability of help. Attitudes that build trust in the relationship with the subject and family, promoting bonding between family and $\mathrm{FH}$ team ${ }^{(6)}$.

The activity of $\mathrm{CHA}$ is relevant in changing health care model, but it is questionable whether the $\mathrm{FH}$ corroborates this potential, given the precarious working conditions and training of these workers ${ }^{(18)}$.
Professional knowledge in primary health care of the person family in mental distress: Le Boterf perspective

Lucchese $R$, Castro $P$, Ba S, Rosalem V, Silva A,

Andrade M, Munari D, Fernandes $I$, Neves $H$ 
When nurses were asked on how they cared for mental suffering at FHU, it was clear that everyone sought resources within the context of work, and sometimes there was a complete "I do not know what to do", beginning a search for specialized service. In situations in which professionals are "not instrumentalized" before the mental suffering, the solution found is the referral of the person and family to the specialized service. Fact that can endanger the resolving capacity of $\mathrm{FH}^{(6)}$ because the excessive and indiscriminate use of this practice compromises their solving capacity and the problem of limiting screening and referrals to specialized services ${ }^{(3)}$.

Through these findings, we believe that these are the knowledge that need to be constituted, due to the absence of instruments, such as a network of attention to effective mental health. The "knowing constitute competencies from resources" was limited to search for specialized service to meet the needs of the one who suffers mentally. However, a solitary demand, generating suffering of the $\mathrm{FH}$ team before certainty in need of partners to act in the FH mental health care.

The third category presented in Box 1 "Knowing how to transpose/Knowing how to integrate multiple knowledge" that established the recognized professional in his/ her repertoire that aggregated, organized and employed or not in a particular professional activity ${ }^{(8)}$.

We must think of this knowledge as all knowledge/ competencies/resources that the professional and the health network have. In this sense, the limitations of the network also reduces the responsiveness of $\mathrm{FH}$. Faced with a situation of mental suffering, subjects mobilized actions for help, but the devices could collaborate not responding to the presented demand.

This context creates a complex situation producing the need for answers from the FH nurse, this triggered schemes to the extent that the problem was keeping. However, we note the formation of "knowing how to determine and interpret indicators of context". Although the most frequent mental suffering action has been to refer to the specialty service and act-driven by biomedical knowledge, there was the record of what we call an enlarged conception of health, in a move to add pathological to other knowledge. Here we find an awareness of the social, economic, relational, dynamic-family processes and pedagogical knowledge, along with the need for contextualization in health situations.

However, this research revealed that other knowledge which constitute the "knowing how to transpose" require investments, such as "Knowing how to memorize multiple situations and solutions-type"; "Knowing to distance oneself, working in two directions"; "Knowing how to mobilize/use their metaknowledge to standardize"; "Knowing to create the conditions for transferability with the aid of transferable schemes". The fragility of this knowledge un- dermines the implementation of knowledge constituted by professional or through actions on health. The competent professional is the one who when implementing their actions, not merely repeats an activity that has been developed, he/she has the capacity to innovate, adapt ${ }^{(8)}$.

However, it is eminent the accuracy of creativity and innovation in $\mathrm{FH}$, view the prospect of deconstruction and reconstruction of new knowledge and practices that enable mental health in $\mathrm{SM}^{(1,13)}$. And it was the conjunction of practice in community, in daily $\mathrm{FH}$ that the subjects showed the demand for transposition of knowledge. Practice is the scenario of the complex situation, where is given dynamically relations.

And the confrontation with this fertile field of transpositions of knowledge and the pursuit of a integrality of health care, which mobilized the professional to question the value of theoretical studies during the training process, as the theory is far from practice. This issue was "Knowing to learn something that they did not translate into real situation", the training has not developed the ability to orchestrate knowledge into action, perhaps by fragmentation of planning and implementation of education in educational or training institutions.

Besides the fragility of the aspects of the social network and health services are also insufficient to restore the person and family suffering mentally. A challenge would be a strengthened and intersectoral network, which counted on sociocultural and political-economic resources along with qualified training ${ }^{(3)}$.

However, FH workplace, where professionals know users and add interpersonal and therapeutic relationships ${ }^{(12)}$, professionals seek other strategies, coming from the universe of informal learning, since they did not realize their usefulness in what was offered in the training or did not find support in the health care network. Also, they act as realized the uniqueness and diversity of subjects, being responsible to the need of the management, decision making and anticipation of actions before experienced problems.

Regarding the qualification of health professionals to meet the demands of mental health in $\mathrm{FH}$, professional training adds more value to the biomedical and psychiatric model. Thus, it does not subsidizing a practice of resilience, based on human relationships, in a form of bond and caring, developing autonomy of the people involved in the process ${ }^{(11)}$.

The category "Knowing how to learn and knowing how to learn to learn", was organized as their approach with the ability to transform his/her experience into action, doing professional practice an opportunity to constitute knowledge.

The constitution of knowledge occurs when we learn, but we do not change our theories (simple circuit), or 
when we change our actions and our theories (double circuit) $)^{(8)}$. In this research, we identified the occurrence of learning in a simple circuit, such as lessons from experience, transforming their actions or describing how to learn, but there was no overcoming of the medical-psychiatric knowledge.

In the material analyzed, we realize that knowing how to learn to learn of the nurse happening in actual practice, exemplifying what would be a past experience, however, arising from the reflection on action ${ }^{(8)}$. Thus, this knowledge came to building as it is being consumed, and its legitimacy in the actions (competence) is reinforced by lived experiences, previously or not.

We realize that training and health services are not related to mental health in $\mathrm{FH}$. We claim this based on two assumptions, the first is due to the formal training of nurses, since it has not yet developed features such as: communication, intra/interpersonal relationship and integrality in the same proportion to the biomedical knowledge. The second is that FH remains the prescriptive logic, attending programs and bureaucratic protocols.

Thus knowing how to learn to learn in the context of mental health practices in $\mathrm{FH}$ was impaired, since the basis of theories of this professional is from professional-disease relationship, with reproduction of a bureaucratic and fragmented work $^{(3)}$. Adding to this, $\mathrm{FH}$ units still operate in a vertical logic, by meeting pre-established demands, measured by production of reports, so mental health in PHC/FH does not appear in these bureaucratic instruments.

Thus, we put to the fifth category to point opportunities in constituting innovative knowing-doing in mental health care in $\mathrm{FH}$, "Knowing how to engage". From this, we see the FH nurse as subject of action, able to make changes. This is a summation of other knowledge, in which the professional can get involved with initiatives and proposals that exceed instructions and procedures ${ }^{(8)}$.

As said, the FH enables activities in defense of life and health promotion with health practices in the community, strengthening the social/public spaces, with interaction between people of society, valuing the group activities ${ }^{(1,3)}$. Counting with popular participation, with dialogues between the various knowledge and subjects, each with its contribution to a given situation ${ }^{(4)}$.

The "engage" and be attentive to equity, accessibility and solution of $\mathrm{FH}$; sensitive enough to perceive the changes of treated subjects, including subjectivity, leading investigated nurses to take some risks. However, such knowledge corroborate the possibility of inclusion of subjects suffering mentally as objects of care from FH teams, with ability to identify the emotional and psychic manifestations of people in the context ${ }^{(2,16)}$. The nurses also interviewed recognized $\mathrm{FH}$ as a field that provides these practices.
And, it is in this space that we live with contradictory practices, not resolving and crystallized to the medicalized model and some progress towards the principles of the SUS and psychosocial care, although still little, inarticulate with the network and not very clear to who performs them ${ }^{(16)}$. In this sense, we consider that the initial advances are nevertheless very important for the construction of this complex process and unprecedented in the history of mental health care.

\section{FINAL CONSIDERATIONS}

Changes in $\mathrm{FH}$ depend on how services are organized and on how they develop their practices. And in this research the "Knowing how to act and react with relevance" in health situations in $\mathrm{FH}$, was responding to the $\mathrm{BMH}$ programs. And given little presence of mental health in the PHC program, nurses end up getting involved much more with other areas than mental health. We cannot ignore that the $\mathrm{BMH}$ programs impose a $\mathrm{FH}$ routine that ensures certain effectiveness, but restricts creativity and the innovative act.

Certainly, the fundamentals of psychosocial has widely contributed to the constitution of relevant doings to attend the demands of people with mental suffering and all people within the FH program. Looking, listening and taking responsibility for actors in their place of living life, paves the way for increased understanding of health needs, gives color and movement to the community and the subjective dimension of relations. However, this reality coexists dialectically with the desire of professionals to act as prescribed in bureaucratic logic, which in our view, brings a misreading of what would be pertinent to know $\mathrm{FH}$, jeopardizing the creation of transformative practices.

In this sense, the knowledge required for constituting competencies for mental health care in FH units are limited, but in motion. Since the data collected along with scientific studies in this area reveal that: even when the reality studied is dialectic; more barriers, difficulties and resistances will be found in the inclusion of mental health in $\mathrm{FH}$; more health actions are guided by the biomedical model; the small steps that professionals of $\mathrm{FH}$ are doing, is historical phenomenon that must be taken into account, since this is a breakthrough in the formatting of a space never before constituted in the history of Brazilian health "care for the person who are mentally suffering in PHC".

Regarding territoriality, the insertion of the $\mathrm{CHA}$ in the community gains a fair status of facilitator in the "contextualization" of knowing-doing, since they forward the identification and monitoring of their subjective needs. An additive to the "knowing how to integrate multiple knowledge", in understanding the health status of people contemplating the pathological, social, economic, relational, dynamic-family and pedagogical processes knowledge.

The greatest difficulty was "knowing how to transpose",
Professional knowledge in primary health care of the person/ family in mental distress: Le Boterf perspective Lucchese $R$, Castro $P$, Ba S, Rosalem V, Silva A, Andrade $M$, Munari D, Fernandes I, Neves $H$ 
the daily $\mathrm{FH}$ teams demand much of this knowledge, but with low transposition of knowing-doing in real situation, since the most common is repetitive action given the psychological suffering referring to the specialty service. A condition that prevents the formation of professional competence, since it is desirable in the search for answers to resolving complex situations is the "orchestrate resources", with knowledge/competence in mental health care in $\mathrm{FH}$.

Still worth the recognition of the limitations of the study, since it represents a reading from the local reality, supported by observation and interviews. However, provides subsidies for other studies and discussion of mental health care in $\mathrm{FH}$ that deserves to be widely investigated.

Finally, we reflect on the ongoing concern among management, professional training and to accumulate knowledge and ministerial programs protocols, format- ting make timely and fragmented that guarantees productivity. There is no apprehension of how to apply all this knowledge, or the use of this bureaucracy in attention to the health needs of people in a practical and dynamic way, just as life is. This is the essence of competence, which contributes to the constitution of innovative knowledge, know how to act, mobilize/transpose acquired resources in situations where manifestations occur, what do we do with a competence/knowledge if we do not effectively use them to modify health practices.

\section{ACKNOWLEDGEMENTS}

We thank CNPq, CAPES and the Foundation for Research Support of the State of Goias (FAPEG) for the financial support provided to this research paper/work through the notice FAPEG No. 006/2012.

\section{REFERENCES}

1. Binotto AL, Santos LL dos, Lourosa QL, Sant'Anna SC, Zanetti ACG, Forster AC, Marques JM de A. Interface saúde da família \& saúde mental: uma estratégia para o cuidado. Rev bras med fam comunidade. Florianópolis 2012, abr-jun; 7(23):83-9.

2. Souza J de, Almeida LY de, Veloso TMC, Barbosa SP, Vedana KGG. Estratégia de Saúde da Família: recursos comunitários na atenção à saúde mental. Acta Paul Enferm 2013; 26(6):594-600.

3. Wetzel C, Pinho LB de, Olschowsky A, Guedes A da C, Camatta MW, Schneider JF. A rede de atenção à saúde mental a partir da Estratégia Saúde da Família. Rev Gaúcha Enferm 2014 jun;35(2):27-32.

4. Costa GD, Cotta RMM, Ferreira MLSM, Reis JR, Franceschini SCC. Saúde da família: desafios no processo de reorientação do modelo assistencial. Rev Bras Enferm, Brasília 2009; 62(1): 113-8

5. Jucá VJS, Nunes MO, Barreto SG. Programa de saúde da família e saúde mental: impasses e desafios na construção da rede. Ciência \& Saúde Coletiva 2009, 14(1):173-82.

6. Lucchese R, Oliveira AGB, Conciani ME, Marcon SR. Saúde mental no Programa Saúde da Família: caminhos e impasses de uma trajetória necessária. Cad. Saúde Pública 2009; 25(9):2033-42.

7. Perrenoud P. Construindo as competências desde a escola. Trad. de Bruno Charles Magne. Porto Alegre: Artmed; 1999.

8. Le Boterf G. Desenvolvendo a competência dos profissionais. 3. ed. rev. Porto Alegre: Artmed; 2003.

9. Bardin L. Análise de Conteúdo. 4ạ. ed. Lisboa: Edições 70; 2009.

10. Perrenoud P. Dez novas competências para ensinar: convite à viagem. Tradução Patrícia Chittoni Ramos. Porto Alegre: Artmed; 2000.
11. Souza LGS, Menandro MCS, Couto LLM, Schimith PB, Lima RP de. Saúde Mental na Estratégia Saúde da Família: revisão da literatura brasileira. Saúde Soc. São Paulo 2012; 21(4):1022-34.

12. Lancet A, Amarante P. Saúde mental e saúde coletiva. In: Campos WSC, Minayo MCS, Akerman M, Drumand Júnior M, Carvalho YM, organizadores. Tratado de saúde coletiva. São Paulo(SP): Hucitec; Rio de Janeiro(RJ): Fiocruz; 2009, p. 615-34.

13. Ministério da Saúde, Secretaria de Atenção à Saúde, Departamento de Ações Programáticas Estratégicas. Saúde Mental no SUS: acesso ao tratamento e mudança do modelo de atenção. Relatório de Gestão 2003-2006. Brasília, DF: Ministério da Saúde, 2007.

14. Camatta MW, Schneider JF. A visão da família sobre o trabalho de profissionais de saúde mental de um centro de atenção psicossocial. Esc Anna Nery Rev Enferm 2009 jul-set; 13 (3): 477-84

15. Rabelo IVM, Tavares RC. Homens-carrapatos e suas muIheres: relato de experiência em Saúde Mental na Estratégia Saúde da Família. Saúde em Debate 2008; 32(78/79/80):133-42.

16. Garuzi M, Achitti MCO, Sato CA, Rocha SA, Spagnuolo RS. Acolhimento na Estratégia Saúde da Família: revisão integrativa. Rev Panam Salud Publica 2014;35(2):144-9.

17. Nunes M, Jucá VJ, Valentim CPB. Ações de saúde mental no Programa Saúde da Família: confluências e dissonâncias das práticas com os princípios das reformas psiquiátrica e sanitária. Cad. Saúde Pública 2007; 23(10):2375-84.

18. Bornstein VJ, Stotz EM. O trabalho dos agentes comunitários de saúde: entre a mediação convencedora e a transformadora. Trab. Educ. Saúde 2009; 6(3):457-80. 